\title{
Impacts of Macronutrients on Gene Expression: Recent Evidence to Understand Productive and Reproductive Performance of Livestock
}

\author{
Md Mahmodul Hasan Sohel ${ }^{1,2^{*}}$, Yusuf Konca ${ }^{2}$, Mehmet Ulas Cinar ${ }^{2}$ \\ ${ }^{1}$ Genome and Stem Cell Centre, Erciyes University, 38039 Kayseri, Turkey. \\ ${ }^{2}$ Department of Animal Science, Faculty of Agriculture, Erciyes University, 38039 Kayseri, Turkey.
}

\section{A R T I C LE IN F O}

\section{Review Article}

Received 21 September 2017

Accepted 28 November 2017

Keywords:

Nutrigenomics

Macronutrient

MicroRNA

Gene expression

Livestock nutrition

*Corresponding Author:

E-mail: sohel@erciyes.edu.tr

\begin{abstract}
A B S T R A C T
In order to identify the effects of nutrients on gene expression and to assess the interactions between genes and nutrition by means of various cutting-edge technologies, the interdisciplinary branch 'Nutrigenomics' was created. Therefore, nutrigenomics corresponds to the use of knowledge and techniques of nutrition, genomics, transcriptomics, proteomics, epigenomics, and metabolomics to seek and explain the cross-talk between nutrition and genes in molecular level. Macronutrients are important dietary signals that control metabolic programming of cells and have important roles in maintaining cellular homeostasis by influencing specific gene expression. Recent advancements in molecular genetics studies, for instance, use of next-generation sequencing, microarray and qPCR array to investigate the expression of transcripts, genes, and miRNAs, has a crucial impact on understanding and quantitative measurement of the impact of dietary macronutrients on gene function. This review will shade a light on the interactions and mechanisms how the dietary source of macronutrients changes the expression of specific mRNA and miRNA. Furthermore, it will highlight the exciting recent findings in relation to animal performance characteristics which eventually help us to identify a dietary target to improve animal production.
\end{abstract}

DOI: https://doi.org/10.24925/turjaf.v6i2.203-212.1573

\section{Introduction}

Expression of genes is regulated by several factors including transcription, processing, the stability of messenger RNA (mRNA), protein synthesis from mRNA, functions of ribosomes and transfer RNAs (tRNAs). Dietary nutrients can modify mRNA or miRNA expressions in both direct and indirect manner. The generation of knowledge regarding the nutritional impact on gene expression and accumulation of the related data has led to open a new era of science known as "nutrigenomics" or "nutritional genomics". Therefore, nutrigenomics examines the interaction of nutrient-gene on a genome-wide scale (Mariman, 2006). As a result, it creates fundamentally new approaches and novel experimental techniques to nutritional research, for instance, different high-throughput techniques that enable the global study of gene expression in response to nutrition. New tools that are available to investigate whole genome sequences to study diet-gene interactions include next-generation sequencing, microarrays, proteomics, metabolomics, and epigenomics.
Beyond inherited genetic abnormalities or disorders, unexpected changes in gene expression may also contribute to disease processes which can be stimulated by various environmental factors. Diet is one of the most important environmental factors altering the cellular environment in most organs including the gastrointestinal tract, liver, heart, and muscle. Macronutrients, particularly proteins, carbohydrates, and lipids have crucial importance in animal growth and development as they are the sources of energy and building blocks required for structural and regulatory unit synthesis of cells (SolonBiet et al., 2015). Macronutrients or their metabolites also have effects on a variety of cellular functions which can be mediated through changes in the levels of circulating hormones, for instance, the release of insulin is regulated by circulating level of glucose molecules. On the other hand, micronutrients also have remarkable effects on the expression of specific genes by regulating intracellular receptors and specific gene promoter interaction (Schuster, 2006). Although the concept of nutrigenomics is a very new notion, it got huge research priority over the 
last decade due to its mood of action, nature of investigation and advancement in molecular genetic research. With the tools of nutrigenomics, it is now possible to explain some of the hidden secrets of epigenetic mechanism. A hypothetical model showing the effects of macronutrients on gene expression as well as on phenotypes of an organism (Figure 1).

Any imbalance in macronutrients may result in developmental and functional disorders. Proteins are the most important macronutrient contributing to the structure of muscles, skin, nails, hairs, wools, and feathers (Laba and Rodziewicz, 2014). Although proteins are not a primary energy source, they can be used as an energy source under specific circumstances. Proteins are composed of 20 amino acids in human and animal bodies (Hoffman and Falvo, 2004). Dietary fat is a major source of energy and vitally important for normal growth and development. Fatty acids and their derived substances have critical roles regulating genes and cellular signaling. However, high fat intake is a very important risk factor for obesity and other metabolic disorders. High-fat diets give rise to overweight, dyslipidemia, insulin and leptin resistance in human and animals (Buettner et al., 2007;
Hariri and Thibault, 2010). Carbohydrates are one of the primary energy sources of living organisms. Carbohydrates are basically classified based on sugar units such as monosaccharides (glucose) oligosaccharides (lactose) and polysaccharides (starch) (Englyst and Hudson, 1996). Among the carbohydrates, glucose has first priority for animal tissues and lactose synthesis in the mammary gland. Therefore, glucose homeostasis is very important for farm animals (Nafikov and Beitz, 2007). High-calorie diets are extensively used by obesity researchers. High-calorie diets induced obesity similar to high-fat diets in experimental animals (Nascimento et al., 2008). It is now evident from several types of research that certain macronutrients have a dynamic influence on the expression of some genes and subsequently alter the abundance of key proteins that may have a crucial role in metabolic pathways and controlling differentiation and cell division. In this review, we accumulated recent exciting findings in livestock nutrigenomics and discussed the impact of studying nutrigenomics to improve the productive and reproductive performance of livestock.

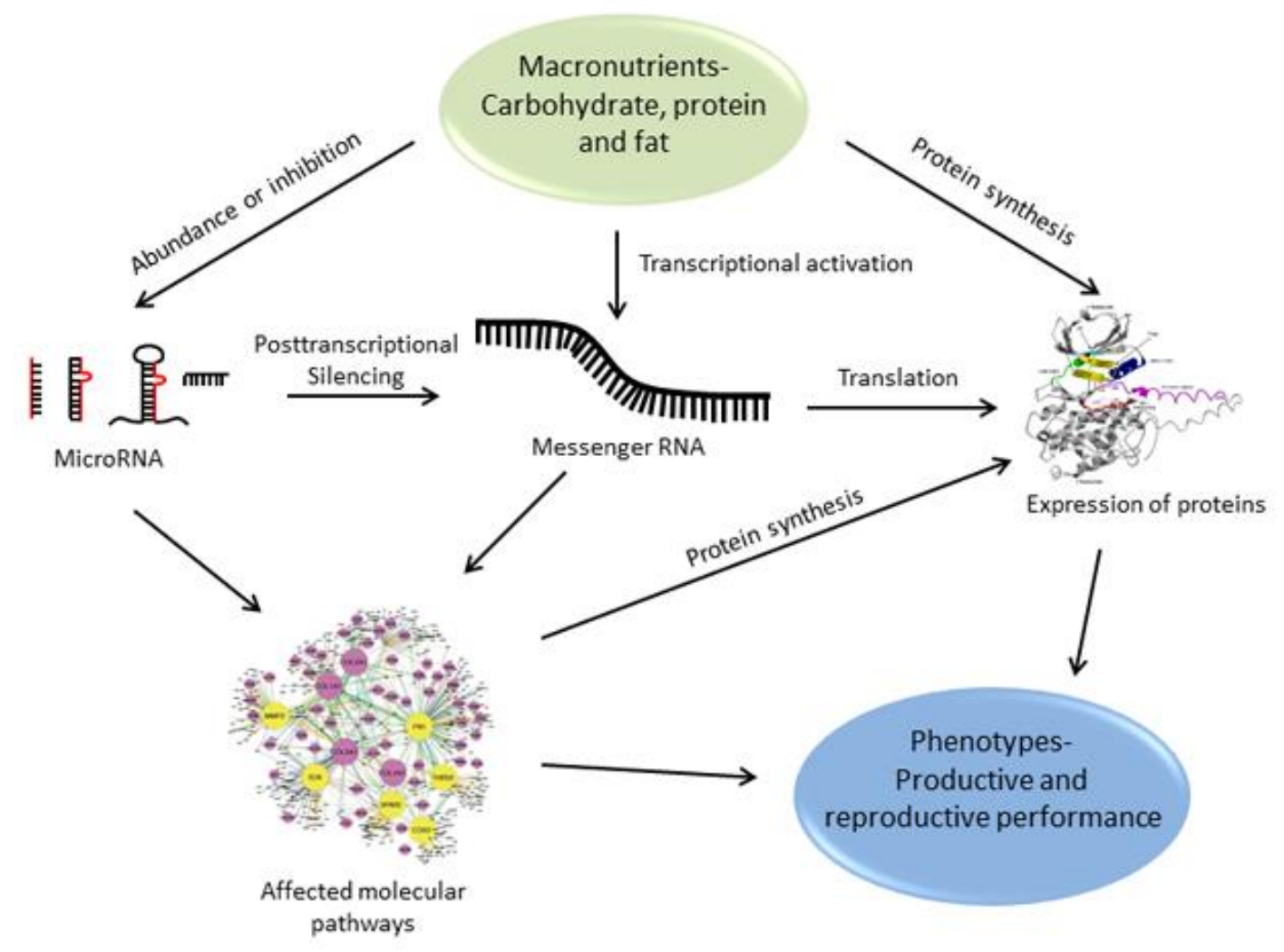

Figure 1 Diagram showing complex interaction between nutrients and genes. The components of this figure were adopted from Sohel, 2016 and Lindin et al., 2014.

\section{How Nutrients Affect Gene Expression}

Dramatic advances have been made in the understanding of the different molecular mechanisms used by nutrients to regulate genes that are essential for their biological roles to carry out normal metabolism (Cousins et al., 2010). Expression of genes can be changed through dietary components in a number of ways. External nutrients may influence the gene expression in both direct and indirect manner. Firstly, in a direct manner, nutrients may bind to transcription factor receptors as a ligand and modulate the expression of genes. Secondly, as an indirect effect, they may be metabolized by primary or secondary metabolic pathways 
thereby altering concentrations of substrates or intermediates and lastly, as another indirect effect, nutrients may alter signal transduction pathways positively or negatively (Schuster, 2006). Diets may induce gene expression via ligand-activated transcription factor-mediated activity, transcription factor acetylation, nutrient transport-influenced transcription factors and nutrient-influenced gene repression via response element placement (Cousins et al., 2010). Fatty acids are the typical example of an indirect effect of nutrients on gene expression. For instance, they undergone metabolization to produce cellular energy and changes intracellular energy balance via the $\beta$-oxidation pathways which may indirectly change the expression of genes through altering in cellular nicotinamide adenine dinucleotide (NAD) homeostasis (Lin and Guarente, 2003) and NAD reoxidation is affecting mitochondrial electron transport activity, is a cofactor for proteins involved in chromatin remodelling. Chromatin remodelling processes have short- and long-term consequences for gene regulation due to reactions such as histone acetylation or DNA methylation that alter access to, and therefore regulation of, eukaryotic genes (Eberharter and Becker, 2002). The resulting differences in an individual due to dietary modification can be attributed to the alterations in their genetic content, which emphasizes the importance of exploring the role of nutrient-gene interactions in the development of livestock phenotype (Dang et al., 2013).

\section{Macronutrients and gene expression}

Gene regulation is a complex process which is carried out through activities of different response elements that potentially influence transcription rate (Cousins, 1999). Dietary nutrient contents may act actively to influence the rate of transcription or may act passively by altering specific signalling pathways. For instance, in ruminant dietary fiber content may influence gene expression in a passive manner by altering mechanical stimuli, metabolites and hormonal signalling produced by the intestinal microflora. Dietary carbohydrate has a strong influence on the expression of genes involved in metabolic pathways predominantly those related to carbohydrate metabolism (Koo et al., 2008). The quantity of dietary carbohydrate also has a dramatic effect on the expression of genes associated with cell adhesion, cell cycle and growth control (Wang et al., 2009; Zhou et al., 2015).

Protein is an essential macronutrient required by humans and animals for their proper growth and development. Malnutrition caused by an insufficient supply of protein may affect the physiologic and pathologic status of an organism. Overfeeding or restriction of dietary protein may cause severe health consequence through altering the expression of genes that are central to several critical pathways (Sharples et al., 2015). The majority of the pleiotropic effects of dietary proteins are mediated by the changes in involved target gene expression. A number of genes have been found to regulate through dietary protein in human as well as different experimental and domestic animals (Hesketh et al., 1998; Starr et al., 2015). For instance, genes encoding the insulin-like growth factor-3 (IGF-3) system are highly sensitive to nutritional status (Straus, 1994; Sharples et al., 2015); any alteration of the expression of these genes comprises one of the major causes of growth restriction in protein malnutrition. Knowledge of such changes will provide us several dimensions into the molecular mechanisms of endocrine and metabolic influence on gene expression in response to protein malnutrition.

Dietary fat is another macronutrient which serves a number of essential functions. However, high dietary fat is considered an important environmental risk factor which is associated with obesity and other metabolic disorders including hypertension, type 2 diabetes, stroke and coronary artery disease (Anunciado-Koza et al., 2015). Although the molecular mechanisms of fat intake with different metabolic syndromes are complex which include different genes and genetic interactions, recent results from several types of research provide cues to complete this complex puzzle. Excessive weight gain and adiposity can be induced by high-fat diets in both animals and humans. When dietary energy intake, in terms of fat, chronically exceeds expenditure may lead to a variety of obesity-related disorders. High dietary fat is sometimes associated with hyperglycemia, hypertriglyceridemia, hyperinsulinemia, high VLDL and low-density lipoprotein (LDL) in circulation. This type of diets also has widespread effects on insulin-responsive tissues. This is particularly true for adipose tissue, which is central to secretes adipokines and bioactive lipids and maintains lipid homeostasis (Almon et al., 2015).

\section{Nutrigenomics: A Tool to Understand Animal Health, Production, and Reproduction}

Animal growth is the outcome of complex combinations of anabolic, catabolic and metabolic processes, which consist of a series of biochemical and physiological reactions, for example, utilization of amino acids and glucose, deposition of intracellular protein and fat, and their regulation by hormones and other factors. Indeed, to have a profitable animal production system the knowledge of animal physiology and nutrition is essential. From a practical point of view, it is clear that gene expression (both mRNA and miRNA) studies will shed a light to identify critical pathways and candidate genes regulating economically important traits in livestock production. Although nutritional strategies and dietary manipulations are key tools to influence livestock production, both nutrition, and genetic makeup strongly influence the productive and reproductive performance of livestock. Nowadays, nutrigenomics is providing new approaches that can be used to have a clear understanding how nutritional management can influence productive and reproductive performance in livestock.

\section{Growth and Development of Skeletal Muscle}

It had already been reported that mammalian embryos primarily dependent on the maternal supply of nutrients, particularly carbohydrate, through the umbilical cord that eventually fuel the developmental activities (Gardner et al., 2000). For instance, skeletal muscle and adipose tissue development can be reprogrammed by maternal nutritional status which is characterized by notable changes in gene expression of sheep fetal tissues 
(Peñagaricano et al., 2014). Furthermore, maternal overnutrition may cause enhanced activities and upregulation of certain enzyme and transporter genes via increasing intestinal functions, while maternal undernutrition caused disturbed fetal intestinal development in newborn pigs (Cao et al., 2014). On the other hand, avian embryos dependent on the nutrients stored in the egg that supplies necessary energy and building blocks for the metabolic activities and growth (Zhai et al., 2011). The in ovo (IO) nutrients of the chick embryo consist mainly of albumin (protein), yolk fat and a trace amount of carbohydrates. However, glucose is the primary source of energy needed for growth and development which comes from carbohydrates. Therefore, to meet the high requirement of glucose, gluconeogenesis of protein or glycolysis of glycogen took place which eventually fuels the hatching activities (Uni et al., 2005). During early stages of development, when there are a handful of cells in the embryo, it is very important that cells are working together and express certain sets of genes so that the embryo can develop properly (Hasegawa et al., 2015). To understand the role of IO administration of carbohydrates on the avian embryo development Bhanja et al., investigated the growth and immune-related candidate gene expression pattern in chick embryo (Bhanja et al., 2015). Interestingly, they found administration of glucose significantly increase the expression of genes related to growth (IGF- I \& II, cGH) during embryonic period and early post-hatch period. Furthermore, IO glucose administration had also influence on the expression pattern of immune-related genes. Finally, the authors concluded that the IO supplementation of carbohydrate is beneficial for embryos in the later stage of growth and development which may mediate through altering growth and immune-related gene expression (Bhanja et al., 2015).

Amino acids (AA) have enormous physiological importance and considered as structural units for tissue proteins and essential substrates for many low molecular weight substances (Kim et al., 2009; Wu et al., 2014). Increasing interest in AA nutrition research reflects their importance to enhance animal production in a global context (Wu et al., 2014). Dietary proteins are the primary suppliers of necessary AA for livestock species. Thus, adequate supply of dietary protein is essential in order to provide different AA and small peptides to the animal for their proper growth and development (Toledo et al., 2014). In contrast, inadequate supply of protein may lead to suboptimal growth and reproduction of livestock animals (Wang et al., 2014). Now, the key factor in formulating new generation diets for livestock requires indepth knowledge of the regulation of protein \& AA metabolism and the function of digestive system in association with digestive enzyme related gene expressions. Although, several studies have been conducted highlighting the role of dietary protein and AA on weight gain (Wang et al., 2014; Kim et al., 2015), productive and reproductive performance (Galassi et al., 2010; Toledo et al., 2014) in pigs, very little is known about the underlying genetic mechanism. In recent years, few studies tried to correlate the dietary supplementation/ manipulation of macronutrients over gene expression. For instance, He et al., demonstrated that the expression of genes related to digestive enzymes and the digestibility \& utilization of AA in growing and finishing pigs can be influenced by the amount of protein available in the diet (He et al., 2015), which subsequently affect the skeletal muscle growth in growing pigs. In addition, supplementation of cysteamine, a degraded form of AA cysteine, enhance the growth of skeletal muscle in finishing pigs by increasing the plasma concentration of IGF-1probably through altering mammalian target of rapamycin (mTOR) and FOXO signalling pathways (Zhou et al., 2015). It has also been shown that maternal isoenergetic diets such as alfalfa haylage, dried corn distillers grains, and corn have marked effects on the expression of myogenic and adipogenic genes that involved in the regulation of cell adhesion, organ development, and tissue development in sheep embryos (Peñagaricano et al., 2014). In addition, maternal overfeeding of macronutrients results in dramatic increase in the expression of genes involved in growth, metabolism, and muscle protein synthesis, while restriction of macronutrients causes loss of expression of those genes in lambs (Hoffman et al., 2016). Similar effects were observed in large domestic ruminants. For instance, maternal intake of starch during the pregnancy regulates the growth, development, and fetal reprogramming through the changes in the expression of imprinted genes including MEG8, H19, IGF2R, and DNMT3a in beef cattle offspring (Wang et al., 2015). Another study conducted to understand how glycine supplementation affects the growth and gene expression in milk-fed young pigs (Wang et al., 2014). Indeed, glycine is an essential AA required in a higher amount to maintain and fulfill multiple physiological functions in the body (Wang et al., 2013). It has been estimated that milk contains only $23 \%$ of daily glycine required for protein synthesis in young animals. Therefore, milk-fed piglets require dietary supplementation of glycine for their proper growth and development (Wang et al., 2014).

Tryptophan (Trp) is one of the important essential AA which is required for protein deposition and multiple metabolic functions (glucose homeostasis, appetite, and immune function) in poultry (Rogers and Pesti, 1990). Appropriate or low level of Trp could enhance the protein deposition in broiler chicks of 8-21 days (Fatufe et al., 2005 ) which may indicate a reduction in proteolysis or the increase in the translation efficiency and the higher capacity for protein synthesis. Genes encoding muscle ring finger-1 (MuRF1), muscle atrophy $\mathrm{F}$ box (MAFbx), and $20 \mathrm{~S}$ proteasome played a crucial part in regulating muscle proteolysis (Gomes et al., 2001) through controlling specific proteolytic system which are potential contributors of muscle degradation. By contrast, synthesis of protein in poultry is regulated by PI3 kinase/protein kinase B/poultry target of the rapamycin (pTOR) signaling pathway (Schiaffino and Mammucari, 2011). Importantly, its regulator p70 S6 kinase (S6K1) can be activated by other anabolic signals including amino acids (such as Trp, Arg, and Leu) or by insulin through a signaling pathway (Sugawara et al. 2007). Clearly, for proper growth and development of skeletal muscle, it is necessary to suppress the proteolytic systems and activate protein synthesis pathways. Recently Pan et al. showed that dietary supplementation of Trp resulted in an 
upregulation of the expression of transmitting tissuespecific (TTS) mRNA and phosphorylation of pTOR and suppress $20 \mathrm{~S}$ protease and cathepsin B mRNA expression in thigh tissue, which subsequently regulates the protein deposition and skeletal muscle growth in thigh tissue in Yangzhou goslings. These findings are a clear indication of genetic and molecular mechanism that may indicate the beneficial effects of dietary supplementation of Trp in improving the protein metabolism (Pan et al., 2013).

\section{Fat Deposition}

Deposition and composition of fat and fatty acids in meat producing animals has received significant interest due to their implications for meat quality characteristics and human health risks. Fat deposition in meat producing animals may consider as beneficial or undesirable depending on its quantity and location. For instance, a huge quantity of adipose tissue accumulation in the subcutaneous and visceral region of beef cattle is considered as 'waste fat' (Gotoh et al., 2009). It has also been recommended, excessive fat deposition, except intramuscular fat, considered as detrimental to carcass quality and constitutes human health hazards (Zhang et al., 2015). In current beef production era, the main goal is to reduce the deposition of 'waste fat,' in the animal body in order to have cost-effective production. Therefore, development of strategies for manipulating deposition of adipose tissue in livestock has been considered as a major breeding goal for many years. In this regard, the knowledge of "Nutrigenomics" can play a crucial role in order to understand and correlate the impact of dietary macronutrient supplement and the underlying molecular mechanisms of fat deposition in farm animals.

Fat accumulation could be influenced by the manipulation of dietary macronutrient content. It has been shown that the content of intramuscular fat can be radically increased by low lysine dietary supplementation in finishing gilts (Katsumata et al., 2005). Furthermore, restricted protein content (Teye et al., 2006), manipulation of dietary energy and protein (Zhang et al., 2014) and conjugated linoleic acid (Zhong et al., 2011) were found to have beneficial effects for intramuscular fat deposition in finishing as well as young porcine. At the metabolic level, fat deposition is a complex and coordinated process and as a result of dynamic balance among fatty acid transportation, lipogenesis and lipolysis in tissue (Jurie et al., 2007). This process is controlled by several metabolic enzymes which are regulated by different functional genes in particular tissues. Any changes in the expression and activities of these lipogenic enzymes and genes, such as stearoyl-CoA desaturase (SCD), fatty acid synthase (FAS), sterol regulatory element binding protein 1 (SREBP-1), acetyl-CoA carboxylase (ACC), and peroxisome proliferator-activated receptor $\gamma(\operatorname{PPAR} \gamma)$ can change the biosynthesis rates of fatty acids (Zhang et al., 2015). Among these, PPAR $\gamma$ is considered as the crucial regulator of the transcription of genes controlling active fat metabolism and adipogenesis which also has adipogenic and lipogenic effects in adipocytes (Sevane et al., 2013). In triglyceride synthesis, SREBP-1 plays a critical role in regulating lipogenic gene expression, including SCD-1, FAS, and ACC1(Postic and Girard, 2008). Studies have demonstrated that SCD facilitates more accessible pool of monounsaturated fatty acids in adipose tissue and therefore, regulate the synthesis of triglyceride (Postic and Girard, 2008). Furthermore, adipocyte-fatty acid binding proteins (A-FABP) and lipoprotein lipase (LPL) have identified as regulators of lipid metabolism in adipose tissue because they are able to modulate the expression of genes involved in lipid metabolism or fatty acids transportation (Zhao et al., 2010). Despite an increase of dietary energy intake (in terms of fat) can improve the digestion and absorption of other nutrients, it may also upregulate the expression of lipogenic genes which eventually cause an increased de novo synthesis of free fatty acid (FFA) resulting higher accumulation of subcutaneous adipose tissue (Zhang et al., 2015).

\section{Milk Production}

The establishment and maintenance of milk synthesis in the mammary gland is a series of complex and coordinated processes which requires the activation of several metabolic and physiological factors along with tight regulation of particular genes. At the cellular level, it is a combination of both the number and the secretory activity of each mammary epithelial cell (MEC) that synthesizes milk. In addition, multiple cell signaling pathways have been identified to be playing a crucial role in regulating milk synthesis (Finucane et al., 2008; Suchyta et al., 2003). The overall efficiency of the milk yield is not only affected by the genetics and local factors within mammary gland but also epigenetic factors such as nutrition (Sejrsen and Purup 1997), photoperiod and heat stress (Dahl and Petitclerc, 2003), milking techniques (Millogo et al., 2011), frequency of milking (Dahl and Petitclerc, 2003) and disease control (Fourichon et al., 1999) have significant effects. Of those, nutrition is the single factor having the greatest effect on milk production of dairy animals. The diets providing essential nutrients in appropriate and adequate quantity enhanced milk production. Clearly, many management and environmental factors besides genetics affect mammary function at the cellular and molecular level. Therefore, milk production in the dairy animals remains open for considerable manipulation for higher production. Consequently, modern scientists are interacting scientific disciplines including genetics, reproduction, and nutrition for higher milk production, apart from simply trying to balance genetic selection (McNamara, 2012).

Oxidative stress is very common in high-yielding dairy cow due to intensive metabolic activity for establishment and maintenance of lactation. Many signaling pathways that are linked to milk synthesis can modulate the formation of reactive oxygen species (ROS) through the direct or indirect mechanism. One of the strategies to improve the nutritional input of ruminant diets in order to minimize oxidative stress is lipid supplementation with n-3 polyunsaturated fatty acids (n-3 PUFAs), however, this approach may result in a higher risk of plasma peroxidation with severe consequence on animal health (Miller et al., 1993). Other strategies include supplementation of dietary antioxidant in the diet containing oxidized fat to enhance the lactation performance and antioxidant activity (Vázquez-Añón et al., 2008), which may work through direct scavenging of 
peroxides or induce the production of antioxidant genes to scavenge reactive oxygen species. In addition, besides endogenous antioxidant molecules supplementation of nonenzymatic antioxidants like vitamin E and Selenium has been shown to be beneficial to improve fertility during heat stress and oxidative stress (Megahed et al., 2008). Supplementation of flex meal has been found to improve the antioxidant capacity through a significant reduction of thiobarbituric acid-reactive substances (TBARS) and increase the abundance of NRF2 (nuclear factor erythroid 2-related factor 2), a central gene for Nrf2 mediated oxidative stress response pathway, in the mammary tissue (Schogor et al., 2013).

Fat is one of the important constituents of ruminant milk that determine the physical and organoleptic properties. Factors affecting fat synthesis in milk are vital in developing nutritional strategies in order to increase the nutritional value of milk and to improve the energy balance. In order to have desired changes in the composition and content of milk fat, it is very important to understand the regulatory effects of macronutrients on milk fat synthesis and the underlying molecular mechanisms dictating mammary lipogenesis. Approximately $50 \%$ of milk fatty acid, including shortand medium-chain fatty acids and one-half of long chain fatty acids are synthesized de novo from acetate and $\beta$ hydroxybutyrate in the mammary gland of dairy cows (Qi et al., 2014). Generally, supplementation of oilseeds and oils in the diet decreases the secretion of fatty acids synthesized de novo in the mammary gland of bovine (Chilliard et al., 2007). Furthermore, feeding diets that cause milk fat depression (high portion of concentrate, marine algal lipids and fish oil) or administration of conjugated linoleic acid intravenously (Gervais et al., 2009) or at the abomasum (Baumgard et al., 2002) also decrease in the output of medium to long chain fatty acids synthesized de novo in ruminant milk which is associated with decrease in acetyl-CoA carboxylase (ACACA) and fatty acid synthase (FASN) mRNA abundance and activity of their transcribed proteins in mammary gland of cows and goats (Bernard et al., 2009). Higher abundance of FASN and ACACA mRNAs in the mammary gland is known to positively regulated fatty acids output in milk (Bernard et al., 2008) suggesting that FASN and ACACA is an important regulator of de novo fatty acid synthesis in ruminant species (Shingfield et al., 2010). In vitro experiments on the bovine mammary epithelial cell line (MAC-T) has demonstrated that acetic acid can enhance the abundance of ACACA mRNA, suggesting it enhance the de novo synthesis of fatty acid in the bovine mammary gland (Jacobs et al., 2013). In addition, Qi et al., showed that certain concentration of saturated long chain fatty acid may have a positive effect on cell proliferation, accumulation of triacylglycerol and expression of mRNA associated with milk fat and protein synthesis in cultured primary bovine epithelial cells after two passages (Qi et al., 2014). However, further studies are necessary to elucidate the underlying mechanisms and effectiveness of direct administration of acetic acid and saturated long-chain fatty acid to increase milk production in livestock.
Abundance or restriction of macronutrients during lactation may influence the milk synthesis in mammary gland through the changes of the expression of some key genes which are crucial in regulating different metabolic pathways. For instance, glucose, the essential macronutrient, is the precursor of lactose synthesis in the mammary gland and glucose requirement are approximately fourfold higher in lactating cow compared to non-lactating cows. As much as $85 \%$ circulating glucose can be consumed by the lactating mammary gland. Therefore, it is logical to think glucose availability in the mammary gland is one of the major regulators of milk production. Many studies have demonstrated that there is a curvilinear increase of milk production with the increase of glucose levels (Rigout et al., 2002; Rulquin et al., 2004), while others reported inconsistent results (AlTrad et al., 2009). Using bovine mammary epithelial cells (BMEC) in vitro, Liu et al., showed that increasing glucose availability may increase the synthesis of milk fat and lactose by modulating the mRNA expression of key genes and subsequently affect the synthesis of milk composition (Liu et al., 2013). On the other hand, restriction of macronutrients during lactation results in a decrease of mRNA concentrations of sterol regulatory element-binding protein target genes involved in lipid synthesis in the liver along with plasma concentration of TAG (Gessner et al., 2015) which may regulate the milk production in lactating pigs. Several of milk traits (milk production, acidity, milk stability etc.) have been found to be negatively correlated with feed restriction in dairy cows (Gabbi et al., 2015). Lactating animals may seek to minimize the effect of nutrient restriction by adopting several adaptation strategies including increased mobilization of body reserved and decreased milk production.

Oilseeds and linseeds are commonly used as a fat source in the ruminant diet which also provides protein and fiber. Numerous experiments have been conducted to study the use of oilseeds, linseeds, and other unconventional diets in order to enhance the milk production as well as composition. Most of the studies reported that oilseed or linseed supplementation has minor or no effect on milk production (Suksombat et al., 2014, 2013), while others reported an increase of milk yield (Johnson et al., 2002). Interestingly, supplementation of sunflower seeds or sunflower oil had a positive effect on milk yield and milk composition in lactating goats (Morsy et al., 2015). Although having an association with bronchiolitis (Sawahata et al., 2010) and cytotoxic activity (Yunita et al., 2013), Sauropus androgynus is traditionally consumed by several Southeast Asian countries and is believed to be an enhancer of milk production during lactation (Bunawan et al., 2015). When feeding S. androgynus leaf extract to lactating mice, it enhanced the expression of two prominent genes (prolactin and oxytocin) regulating milk production and subsequently, increased milk production (Soka et al., 2010) suggesting their potential use to increase milk production in livestock ruminants (Gabbi et al., 2015). 


\section{Enhance Reproductive Performance}

Although several studies have conducted to demonstrate the interrelation between nutrition and reproduction covering different livestock species (Thatcher et al., 2011; Lei et al., 2014), this relationship is dynamic and extremely complex. Sub-optimal reproductive performance in farm animals has been well documented in terms of production system efficiency as well as economic viability (Maciel et al., 2015). Reproductive performance can be influenced by many factors, including genetics, season, disease and more importantly nutritional management. Nutrition is one of the most important environmental factors that have a significant impact on numerous reproductive functions including hormone production, ovum \& sperm viability, fertilization, and early embryonic development both in vivo and in vitro. Increased number of researchers are trying to assess the relationship between interactions and matching the puzzles of these varying effects on reproduction. Nutritional factors may have an influence on different stages of the reproduction starting form follicular growth to the birth of an offspring. Metaanalyses and meta-regression of nutritional effects on reproductive parameters demonstrated that there was a negative effect of soluble proteins and positive effects of lipids on reproductive performance in lactating dairy cows (Rodney et al., 2015). Although low heritability of reproductive traits indicating the complex and multifactorial nature of this trait, recent studies showed that the estimated genetic merit for reproductive traits is increasing (Berry et al., 2014).

Intensive genetic selection together with considerable improvement in dietary nutrition plan leads to significant increases in average milk production. Unfortunately, there is a negative relationship between the productivity and the fertility. High yielding dairy animals required a high nutritional plan, rich in energy and protein, to mitigate the higher requirement of nutrients during the late pregnancy and early lactation to avoid negative energy balance (NEB). Inadequate macronutrient supply may result in an imbalance in endocrine and metabolic status which is associated with the resumption of ovulatory cycles, noncompetent oocytes, and low embryo quality, and finally establishment and maintenance of pregnancy. Indeed, diets reach in carbohydrates can enhance the energy status and consequently increase the percentage of active ovaries in the early postpartum period (Solon-Biet et al., 2015), however, the quality of oocyte and embryo may suffer from such insulinogenic diets. Interestingly, Sales et al., found different dietary energy levels have no influence on the oocyte numbers and quality. In addition, high energy diet intake for a long period may decrease the in vitro production of embryos in Bos indicus cows by causing a hyperinsulinemic state and inducing the downregulation of cellular metabolism genes (Sales et al., 2015).

High dietary fat has beneficial effects on stimulation of the ovarian steroid production which ultimately increase the ovarian activity. However, it may also cause caused impaired oocyte and embryo quality characterized by excessive lipid accumulation and an altered energy metabolism. Higher ovarian activity $(93.3 \%, 14$ out of 15$)$ in buffaloes has also been observed in high lipid diet, while significantly lower ovarian activity (20\%, 3 out of 15) found in low lipid diet (Hussein and Abdel-Raheem, 2013). In contrast, high lipid diet leads to produce oocytes with significantly higher lipid accumulation, abnormal meiotic spindles, and lower ATP compared to control diet (Reynolds et al., 2015).

High-protein diets can stimulate the milk production and ammonia and urea concentrations in the blood, however, it has often been associated with altered intrafollicular, oviductal and uterine environments resulting low reproductive performance (Laven and Drew, 1999; Law et al., 2009). In contrast, high protein diets may result in a higher growth pattern during the growing period which increased the fertility, decreased mortality and improved offspring performance in broiler breeder (van Emous et al., 2015). Furthermore, supplementation of biotin has been shown to be positively affected the reproductive performance through the upregulation of avidin-related protein-2 mRNA levels in the oviduct of broiler hens (Daryabari et al., 2015). The microenvironment contains oocytes and embryos are highly sensitive to these dietary changes and perhaps caused disturbed fertilization, maturation or early cleavage and development of the fetus.

Dietary macronutrients may act on many levels of the ovarian-hypothalamus-hypophyseal axis, which may be directly reflected in reproductive efficiency in farm animal (Leroy et al., 2008; Garcia-Garcia, 2012). In addition, acute or chronic changes in the dietary macronutrient may alter the release and synthesis hormones related to reproductive and metabolic process, follicular growth and oocyte quality.

\section{Conclusion}

Nutrigenomics opens a new era of working with nutrition and genetics and this knowledge will help us to determine how food interferes with the genetics of an organism and what will be the responses to these interferences in terms of phenotype. In mitigating the problems focusing on animal production, disease, and health, nutrigenomics is the potential tool for nutritional research in molecular level. In future, a combination of both innovative nutritional research and updated molecular technologies will indubitably enhance our basic understanding of nutrient-gene interaction and help us to define new methods for managing animal production and reproduction. Therefore, it will be possible to formulate a nutritional plan for livestock depending on their genotype which ultimately enhance productive and reproductive performances. Finally, it could be possible to get the desired livestock performance in terms of disease, health, and production through targeting the specific genes by nutritional manipulation. Since the introduction of nutrigenomics into the "omics" group, there was an upgrade of how nutritionists, geneticist and other professionals on evaluating and treating different diseases in humans and enhance the productive and reproductive performance in livestock species. Nevertheless, there is still a long way to go on Nutrigenomics, as further research needs to be done in order to connect an animal's genetic profile, diet, and environmental habits. 


\section{References}

Al-Trad B, Reisberg K, Wittek T, Penner GB, Alkaassem A, Gäbel G, Fürll M, Aschenbach JR. 2009. Increasing intravenous infusions of glucose improve body condition but not lactation performance in midlactation dairy cows. J. Dairy Sci., 92: 5645-58. doi:10.3168/jds.2009-2264

Almon R, Xue B, Wang X, Nie J, DuBois D, Jusko W. 2015. Effects of High Fat Feeding on Adipose Tissue Gene Expression in Diabetic Goto-Kakizaki Rats. Gene Regul. Syst. Bio., 9: 15-26. doi:10.4137/GRSB.S25172

Anunciado-Koza RP, Higgins DC, Koza RA. 2015. Adipose tissue Mest and Sfrp5 are concomitant with variations of adiposity among inbred mouse strains fed a non-obesogenic diet Biochimie., 124: 134-140. doi: 10.1016/j.biochi.2015.05.007

Baumgard LH, Matitashvili E, Corl BA, Dwyer DA, Bauman DE. 2002. trans-10, cis-12 conjugated linoleic acid decreases lipogenic rates and expression of genes involved in milk lipid synthesis in dairy cows. J. Dairy Sci., 85: 2155-63. doi:10.3168/jds. S0022-0302(02)74294-X

Bernard L, Bonnet M, Leroux C, Shingfield KJ, Chilliard Y. 2009. Effect of sunflower-seed oil and linseed oil on tissue lipid metabolism, gene expression, and milk fatty acid secretion in Alpine goats fed maize silage-based diets. J. Dairy Sci., 92: 6083-94. doi:10.3168/jds.2009-2048

Bernard L, Leroux C, Chilliard Y. 2008. Expression and nutritional regulation of lipogenic genes in the ruminant lactating mammary gland. Adv. Exp. Med. Biol., 606: 67-108. doi:10.1007/978-0-387-74087-4_2

Berry DP, Wall E, Pryce JE. 2014. Genetics and genomics of reproductive performance in dairy and beef cattle. Animal., 8 Suppl 1: 105-21. doi:10.1017/S1751731114000743

Bhanja SK, Goel A, Pandey N, Mehra M, Majumdar S, Mandal AB. 2015. In ovo carbohydrate supplementation modulates growth and immunity-related genes in broiler chickens. J. Anim. Physiol. Anim. Nutr. (Berl)., 99: 163-73. doi:10.1111/jpn. 12193

Buettner R, Schölmerich J, Bollheimer LC. 2007. High-fat diets: modeling the metabolic disorders of human obesity in rodents. Obesity (Silver Spring)., 15: 798-808 doi:10.1038/oby.2007.608

Bunawan H, Bunawan SN, Baharum SN, Noor NM. 2015. Sauropus androgynus (L.) Merr. Induced Bronchiolitis Obliterans: From Botanical Studies to Toxicology. Evidence-Based Complement. Altern. Med. 2015, 1-7. doi:10.1155/2015/714158. Available from: https://www.hindawi.com/journals/ecam/2015/714158/ [Accessed 19/12/2016]

Cao M, Che L, Wang J, Yang M, Su G, Fang Z, Lin Y, Xu S, Wu D. 2014. Effects of maternal over- and undernutrition on intestinal morphology, enzyme activity, and gene expression of nutrient transporters in newborn and weaned pigs. Nutrition., 30: 14427. doi:10.1016/j.nut.2014.04.016

Chilliard Y, Glasser F, Ferlay A, Bernard L, Rouel J, Doreau M. 2007. Diet, rumen biohydrogenation and nutritional quality of cow and goat milk fat. Eur. J. Lipid Sci. Technol., 109: 828855. doi:10.1002/ejlt.200700080

Cousins RJ. 1999. Nutritional regulation of gene expression. Am. J. Med., 106: 20S-23S; discussion 50S-51S. doi.org/10.1016/S0002-9343(98)00342-8

Cousins RJ, Aydemir TB, Lichten LA. 2010. Plenary Lecture 2 Transcription factors, regulatory elements and nutrient-gene communication. Proc. Nutr. Soc., 69: 91-94. doi:10.1017/S0029665109991790

Dahl GE, Petitclerc D. 2003. Management of photoperiod in the dairy herd for improved production and health. J. Anim. Sci., 81: 11-17.

Dang Y, Li L, Guo W, Xue Z, Liu Y. 2013. Convergent Transcription Induces Dynamic DNA Methylation at disiRNA Loci. PLoS Genet., 9: e1003761. doi:10.1371/journal.pgen. 1003761

Daryabari H, Akhlaghi A, Zamiri MJ, Pirsaraei ZA, Mianji GR, Deldar H, Eghbalian AN. 2015. Oral administration of supplementary biotin differentially influences the fertility rate and oviductal expression of avidin and avidin-related protein- 2 in low- and high-fertility broiler line hens. Poult. Sci., 94: 28995. doi:10.3382/ps/peu073
Eberharter A, Becker PB. 2002. Histone acetylation: a switch between repressive and permissive chromatin. Second in review series on chromatin dynamics. EMBO Rep., 3: 224-9. doi:10.1093/embo-reports/kvf053

Englyst HN, Hudson GJ. 1996. The classification and measurement of dietary carbohydrates. Food Chem., 57: 15-21. doi:10.1016/0308-8146(96)00056-8

Fatufe AA, Hirche F, Rodehutscord M. 2005. Estimates of individual factors of the tryptophan requirement based on protein and tryptophan accretion responses to increasing tryptophan supply in broiler chickens 8-21 days of age. Arch. Anim. Nutr., 59: 181-90. doi:10.1080/17450390500147925

Finucane KA, McFadden TB, Bond JP, Kennelly JJ, Zhao F-Q. 2008. Onset of lactation in the bovine mammary gland: gene expression profiling indicates a strong inhibition of gene expression in cell proliferation. Funct. Integr. Genomics., 8: 251-64. doi:10.1007/s10142-008-0074-y

Fourichon C, Seegers H, Bareille N, Beaudeau F. 1999. Effects of disease on milk production in the dairy cow: a review. Prev. Vet. Med., 41: 1-35. doi:10.1016/S0167-5877(99)00035-5

Gabbi AM, McManus CM, Zanela MB, Stumpf MT, Barbosa RS, Fruscalso V, Thaler Neto A, Schmidt FA, Fischer V. 2015. Milk traits of lactating cows submitted to feed restriction. Trop. Anim. Health Prod., 48: 37-43. doi:10.1007/s11250-015-0916-2

Galassi G, Colombini S, Malagutti L, Crovetto GM, Rapetti L. 2010. Effects of high fibre and low protein diets on performance, digestibility, nitrogen excretion and ammonia emission in the heavy pig. Anim. Feed Sci. Technol., 161: 140148. doi:10.1016/j.anifeedsci.2010.08.009

Garcia-Garcia RM. 2012. Integrative control of energy balance and reproduction in females. ISRN Vet. Sci., 2012: 1-13. doi: $10.5402 / 2012 / 121389$

Gardner DK, Pool TB, Lane M. 2000. Embryo nutrition and energy metabolism and its relationship to embryo growth, differentiation, and viability. Semin. Reprod. Med., 18: 205-18. doi: 10.1055/s-2000-12559

Gervais R, McFadden JW, Lengi AJ, Corl BA, Chouinard PY. 2009. Effects of intravenous infusion of trans-10, cis-12 18:2 on mammary lipid metabolism in lactating dairy cows. J. Dairy Sci., 92: 5167-77. doi:10.3168/jds.2009-2281

Gessner DK, Gröne B, Rosenbaum S, Most E, Hillen S, Becker S, Erhardt G, Reiner G, Ringseis R, Eder K. 2015. Effect of a negative energy balance induced by feed restriction in lactating sows on hepatic lipid metabolism, milk production and development of litters. Arch. Anim. Nutr., 69: 399-410. doi:10.1080/1745039X.2015.1075669

Gomes MD, Lecker SH, Jagoe RT, Navon A, Goldberg AL. 2001. Atrogin-1, a muscle-specific F-box protein highly expressed during muscle atrophy. Proc. Natl. Acad. Sci. U. S. A., 98: 14440-5. doi:10.1073/pnas.251541198

Gotoh T, Albrecht E, Teuscher F, Kawabata K, Sakashita K, Iwamoto H, Wegner J. 2009. Differences in muscle and fat accretion in Japanese Black and European cattle. Meat Sci., 82: 300-8. doi:10.1016/j.meatsci.2009.01.026

Hariri N, Thibault L. 2010. High-fat diet-induced obesity in animal models. Nutr. Res. Rev., 23: 270-99. doi:10.1017/S0954422410000168

Hasegawa Y, Taylor D, Ovchinnikov DA, Wolvetang EJ, de Torrenté L, Mar J.C. 2015. Variability of Gene Expression Identifies Transcriptional Regulators of Early Human Embryonic Development. PLOS Genet., 11: e1005428. doi:10.1371/journal.pgen. 1005428

He L, Wu L, Xu Z, Li T, Yao K, Cui Z, Yin Y, Wu G. 2015. Lowprotein diets affect ileal amino acid digestibility and gene expression of digestive enzymes in growing and finishing pigs. Amino Acids., 48: 21-30. doi:10.1007/s00726-015-2059-1

Hesketh JE, Vasconcelos MH, Bermano G. 1998. Regulatory signals in messenger RNA: determinants of nutrient-gene interaction and metabolic compartmentation. Br. J. Nutr., 80: 307-21.

Hoffman JR, Falvo MJ. 2004. Protein - Which is Best? J. Sports Sci. Med., 3: 118-30. 
Hoffman M L, Peck KN, Wegrzyn JL, Reed SA, Zinn SA, Govoni KE. 2016. Poor maternal nutrition during gestation alters the expression of genes involved in muscle development and metabolism in lambs. J. Anim. Sci., 94: 3093-3099. doi:10.2527/jas.2016-0570

Hussein HA, Abdel-Raheem SM. 2013. Effect of feed intake restriction on reproductive performance and pregnancy rate in Egyptian buffalo heifers. Trop. Anim. Health Prod., 45: 1001-6. doi:10.1007/s11250-012-0324-9

Jacobs AAA, Dijkstra J, Liesman JS, Vandehaar MJ, Lock AL, van Vuuren AM, Hendriks WH, van Baal J. 2013. Effects of shortand long-chain fatty acids on the expression of stearoyl-CoA desaturase and other lipogenic genes in bovine mammary epithelial cells. Animal., 7: 1508-16. doi: $10.1017 /$ S175173111300061X

Johnson KA, Kincaid RL, Westberg HH, Gaskins CT, Lamb BK, Cronrath JD. 2002. The effect of oilseeds in diets of lactating cows on milk production and methane emissions. J. Dairy Sci., 85: 1509-15. doi:10.3168/jds.S0022-0302(02)74220-3

Jurie C, Cassar-Malek I, Bonnet M, Leroux C, Bauchart D, Boulesteix P, Pethick DW, Hocquette JF. 2007. Adipocyte fatty acid-binding protein and mitochondrial enzyme activities in muscles as relevant indicators of marbling in cattle. J. Anim. Sci., 85: 2660-9. doi:10.2527/jas.2006-837

Katsumata M, Kobayashi S, Matsumoto M, Tsuneishi E, Kaji Y. 2005. Reduced intake of dietary lysine promotes accumulation of intramuscular fat in the Longissimus dorsi muscles of finishing gilts. Anim. Sci. J., 76: 237-244. doi:10.1111/j.17400929.2005.00261.x

Kim BG, Petersen GI, Hinson RB, Allee GL, Stein HH. 2009. Amino acid digestibility and energy concentration in a novel source of high-protein distillers dried grains and their effects on growth performance of pigs. J. Anim. Sci., 87: 4013-4021. doi:10.2527/jas.2009-2060

Kim K, Goel A, Lee S, Choi Y, Chae B-J. 2015. Comparative ileal amino acid digestibility and growth performance in growing pigs fed different level of canola meal. J. Anim. Sci. Technol., 57: 21. doi:10.1186/s40781-015-0055-3

Koo H-Y, Wallig MA, Chung BH, Nara TY, Cho BHS, Nakamura MT. 2008. Dietary fructose induces a wide range of genes with distinct shift in carbohydrate and lipid metabolism in fed and fasted rat liver. Biochim. Biophys. Acta., 1782: 341-8. doi:10.1016/j.bbadis.2008.02.007

Laba W, Rodziewicz A. 2014. Biodegradation of hard keratins by two bacillus strains. Jundishapur J. Microbiol., 7: e8896. doi: $10.5812 / \mathrm{jjm} .8896$

Laven RA, Drew SB. 1999. Dietary protein and the reproductive performance of cows. Vet. Rec., 145: 687-95.

Law RA, Young FJ, Patterson DC, Kilpatrick DJ, Wylie ARG, Mayne CS. 2009. Effect of dietary protein content on the fertility of dairy cows during early and mid lactation. J. Dairy Sci., 92: 2737-46. doi:10.3168/jds.2008-1420

Leroy JLMR, Van Soom A, Opsomer G, Goovaerts IGF, Bols PEJ. 2008. Reduced fertility in high-yielding dairy cows: are the oocyte and embryo in danger? Part II. Mechanisms linking nutrition and reduced oocyte and embryo quality in highyielding dairy cows. Reprod. Domest. Anim., 43: 623-32. doi:10.1111/j.1439-0531.2007.00961.x

Lin S-J, Guarente L. 2003. Nicotinamide adenine dinucleotide, a metabolic regulator of transcription, longevity and disease. Curr. Opin. Cell Biol., 15: 241-246. doi:10.1016/S09550674(03)00006-1

Lindin I, Wuxiuer Y, Ravna AW, Ugo Moens U, Sylte I. 2014. Comparative Molecular Dynamics Simulations of MitogenActivated Protein Kinase-Activated Protein Kinase 5. Int. J. Mol. Sci., 15: 4878-4902. doi:10.3390/ijms 15034878

Liu H, Zhao K, Liu J. 2013. Effects of Glucose Availability on Expression of the Key Genes Involved in Synthesis of Milk Fat, Lactose and Glucose Metabolism in Bovine Mammary

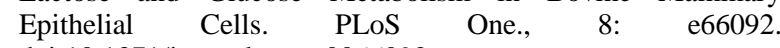
doi:10.1371/journal.pone.0066092

Maciel SMA, Fair MD, Scholtz MM, Neser FWC. 2015. Factors influencing the reproduction and production performance of the Nguni cattle ecotypes in South Africa. Trop. Anim. Health Prod., 48:75-85. doi:10.1007/s11250-015-0923-3
Mariman ECM. 2006. Nutrigenomics and nutrigenetics: the "omics" revolution in nutritional science. Biotechnol. Appl. Biochem., 44: 119-28. doi:10.1042/BA20050112

McNamara JP. 2012. Ruminant Nutrition Symposium: a systems approach to integrating genetics, nutrition, and metabolic efficiency in dairy cattle. J. Anim. Sci., 90: 1846-54. doi:10.2527/jas.2011-4609

Megahed GA, Anwar MM, Wasfy SI, Hammadeh ME. 2008. Influence of heat stress on the cortisol and oxidant-antioxidants balance during oestrous phase in buffalo-cows (Bubalus bubalis): thermo-protective role of antioxidant treatment. Reprod. Domest. Anim., 43: 672-7. doi:10.1111/j.14390531.2007.00968.x

Miller JK, Brzezinska-Slebodzinska E, Madsen FC. 1993. Oxidative stress, antioxidants, and animal function. J. Dairy Sci., 76: 2812-23. doi:10.3168/jds.S0022-0302(93)77620-1

Millogo V, Norell L, Ouédraogo GA, Svennersten-Sjaunja K, Agenäs S. 2011. Effect of different hand-milking techniques on milk production and teat treatment in Zebu dairy cattle. Trop. Anim. Health Prod., 44: 1017-1025. doi:10.1007/s11250-0110035-7

Morsy TA, Kholif SM, Kholif AE, Matloup OH, Salem AZM, Elella AA. 2015. Influence of Sunflower Whole Seeds or Oil on Ruminal Fermentation, Milk Production, Composition, and Fatty Acid Profile in Lactating Goats. Asian-Australasian J. Anim. Sci., 28: 1116-22. doi:10.5713/ajas.14.0850

Nafikov RA, Beitz DC. 2007. Carbohydrate and lipid metabolism in farm animals. J. Nutr., 137: 702-5.

Nascimento AF, Sugizaki MM, Leopoldo AS, Lima-Leopoldo AP, Luvizotto RAM, Nogueira CR, Cicogna AC. 2008. A hypercaloric pellet-diet cycle induces obesity and co-morbidities in Wistar rats. Arq. Bras. Endocrinol. Metabol., 52: 968-74.

Pan X, Wei Z, Wang H, Yu L, Liang X. 2013. Effects of dietary tryptophan on protein metabolism and related gene expression in Yangzhou goslings under different feeding regimens. Poult. Sci., 92: 3196-204. doi:10.3382/ps.2012-02953

Peñagaricano F, Wang X, Rosa GJ, Radunz AE, Khatib H. 2014. Maternal nutrition induces gene expression changes in fetal muscle and adipose tissues in sheep. BMC Genomics., 15: 1034. doi:10.1186/1471-2164-15-1034

Postic C, Girard J. 2008. Contribution of de novo fatty acid synthesis to hepatic steatosis and insulin resistance: lessons from genetically engineered mice. J. Clin. Invest., 118: 829-38. doi:10.1172/JCI34275

Qi L, Yan S, Sheng R, Zhao Y, Guo X. 2014. Effects of Saturated Long-chain Fatty Acid on mRNA Expression of Genes Associated with Milk Fat and Protein Biosynthesis in Bovine Mammary Epithelial Cells. Asian-Australasian J. Anim. Sci., 27: 414-21. doi:10.5713/ajas.2013.13499

Reynolds KA, Boudoures AL, Chi MM-Y, Wang Q, Moley KH. 2015. Adverse effects of obesity and/or high-fat diet on oocyte quality and metabolism are not reversible with resumption of regular diet in mice. Reprod. Fertil. Dev., 27: 716-24. doi:10.1071/RD14251

Rigout S, Lemosquet S, van Eys JE, Blum JW, Rulquin H. 2002. Duodenal glucose increases glucose fluxes and lactose synthesis in grass silage-fed dairy cows. J. Dairy Sci., 85: 595-606. doi:10.3168/jds.S0022-0302(02)74113-1

Rodney RM, Celi P, Scott W, Breinhild K, Lean IJ. 2015. Effects of dietary fat on fertility of dairy cattle: A meta-analysis and metaregression. J. Dairy Sci., 98: 5601-20. doi:10.3168/jds.20159528

Rogers SR, Pesti GM. 1990. The influence of dietary tryptophan on broiler chick growth and lipid metabolism as mediated by dietary protein levels. Poult. Sci., 69: 746-56.

Rulquin H, Rigout S, Lemosquet S, Bach A. 2004. Infusion of glucose directs circulating amino acids to the mammary gland in well-fed dairy cows. J. Dairy Sci., 87: 340-9. doi:10.3168/jds.S0022-0302(04)73173-2

Sales JNS, Iguma LT, Batista RITP, Quintão CCR, Gama MAS, Freitas C, Pereira MM, Camargo LSA, Viana JHM, Souza JC, Baruselli PS. 2015. Effects of a high-energy diet on oocyte quality and in vitro embryo production in Bos indicus and Bos taurus cows. J. Dairy Sci., 98: 3086-99. doi:10.3168/jds.20148858 
Sawahata M, Ogura T, Tagawa A, Takahashi H, Yazawa T, Matsuura M, Takemura T. 2010. Sauropus androgynusassociated bronchiolitis obliterans of mother and daughter autopsy report. Respir. Med. CME., 3: 214-217. doi:10.1016/j.rmedc.2009.11.005

Schiaffino S, Mammucari C. 2011. Regulation of skeletal muscle growth by the IGF1-Akt/PKB pathway: insights from genetic models. Skelet. Muscle., 4: doi:10.1186/2044-5040-1-4

Schogor ALB, Palin M-F, dos Santos GT, Benchaar C, Lacasse P, Petit HV. 2013. Mammary gene expression and activity of antioxidant enzymes and oxidative indicators in the blood, milk, mammary tissue and ruminal fluid of dairy cows fed flax meal. Br. J. Nutr., 110: 1743-1750. doi:10.1017/S0007114513001220

Schuster GU. 2006. Nutrients and Gene Expression, in: Nutritional Genomics. Hoboken, NJ, USA: John Wiley \& Sons, Inc. doi:10.1002/0471781797.ch7

Sejrsen K, Purup S. 1997. Influence of prepubertal feeding level on milk yield potential of dairy heifers: a review. J. Anim. Sci., 75: 828-35. doi:10.2527/1997.753828x

Sevane N, Armstrong E, Cortés O, Wiener P, Wong RP, Dunner S. 2013. Association of bovine meat quality traits with genes included in the PPARG and PPARGC1A networks. Meat Sci., 94: 328-35. doi:10.1016/j.meatsci.2013.02.014

Sharples AP, Hughes DC, Deane CS, Saini A, Selman C, Stewart CE. 2015. Longevity and skeletal muscle mass: the role of IGF signalling, the sirtuins, dietary restriction and protein intake. Aging Cell., 14: 511-23. doi:10.1111/acel.12342

Shingfield KJ, Bernard L, Leroux C, Chilliard Y. 2010. Role of trans fatty acids in the nutritional regulation of mammary lipogenesis in ruminants. Animal., 4: 1140-66. doi: $10.1017 /$ S1751731110000510

Sohel MMH. 2016. Extracellular/Circulating MicroRNAs: Release Mechanisms, Functions and Challenges. Achiev. Life Sci., 10: 175-186. doi:10.1016/j.als.2016.11.007

Soka S, Alam H, Boenjamin N, Agustina TW, Suhartono MT. 2010. Effect of Sauropus androgynus leaf extracts on the expression of prolactin and oxytocin genes in lactating BALB/C mice. J. Nutrigenet. Nutrigenomics., 3: 31-6. doi:10.1159/000319710

Solon-Biet SM, Walters KA, Simanainen UK, McMahon AC, Ruohonen K, Ballard JWO, Raubenheimer D, Handelsman DJ, Le Couteur DG, Simpson SJ. 2015. Macronutrient balance, reproductive function, and lifespan in aging mice. Proc. Natl. Acad. Sci., 112: 3481-6. doi:10.1073/pnas.1422041112

Starr LM, Koski KG, Scott ME. 2015. Expression of growth-related genes in the mouse placenta is influenced by interactions between intestinal nematode (Heligmosomoides bakeri) infection and dietary protein deficiency. Int. J. Parasitol., 46: 97-104. doi:10.1016/j.ijpara.2015.09.004

Straus DS. 1994. Nutritional regulation of hormones and growth factors that control mammalian growth. FASEB J., 8: 6-12.

Suchyta SP, Sipkovsky S, Halgren RG, Kruska R, Elftman M, Weber-Nielsen M, Vandehaar MJ, Xiao L, Tempelman RJ, Coussens PM. 2003. Bovine mammary gene expression profiling using a cDNA microarray enhanced for mammaryspecific transcripts. Physiol. Genomics., 16: 8-18. doi:10.1152/physiolgenomics.00028.2003

Sugawara T, Ito Y, Nishizawa N, Nagasawa T. 2007. Supplementation with dietary leucine to a protein-deficient diet suppresses myofibrillar protein degradation in rats. J. Nutr. Sci. Vitaminol., 53: 552-5.

Suksombat W, Meeprom C, Mirattanaphrai R. 2013. Milk production, milk composition, live weight change and milk Fatty Acid composition in lactating dairy cows in response to whole linseed supplementation. Asian-Australasian J. Anim. Sci., 26: 1111-8. doi:10.5713/ajas.2013.13027

Suksombat W, Thanh LP, Meeprom C, Mirattanaphrai R. 2014. Effects of linseed oil or whole linseed supplementation on performance and milk Fatty Acid composition of lactating dairy cows. Asian-Australasian J. Anim. Sci., 27: 951-9. doi:10.5713/ajas.2013.13665

Teye GA, Sheard PR, Whittington FM, Nute GR, Stewart A, Wood JD. 2006. Influence of dietary oils and protein level on pork quality. 1. Effects on muscle fatty acid composition, carcass, meat and eating quality. Meat Sci., 73: 157-65. doi:10.1016/j.meatsci.2005.11.010
Thatcher W, Santos JEP, Staples C.R. 2011. Dietary manipulations to improve embryonic survival in cattle. Theriogenology., 76: 1619-31. doi:10.1016/j.theriogenology.2011.06.005

Toledo JB, Furlan AC, Pozza PC, Carraro J, Moresco G, Ferreira SL, Gallego AG. 2014. Reduction of the crude protein content of diets supplemented with essential amino acids for piglets weighing 15 to 30 kilograms. Rev. Bras. Zootec., 43: 301-309. doi:10.1590/S1516-35982014000600004

van Emous RA, Kwakkel RP, van Krimpen MM, van den Brand H, Hendriks WH. 2015. Effects of growth patterns and dietary protein levels during rearing of broiler breeders on fertility, hatchability, embryonic mortality, and offspring performance. Poult. Sci., 94: 681-91. doi:10.3382/ps/pev024

Vázquez-Añón M, Nocek J, Bowman G, Hampton T, Atwell C, Vázquez P, Jenkins T. 2008. Effects of feeding a dietary antioxidant in diets with oxidized fat on lactation performance and antioxidant status of the cow. J. Dairy Sci., 91: 3165-72. doi:10.3168/jds.2007-0737

Wang B, Bobe G, LaPres JJ, Bourquin LD. 2009. Dietary carbohydrate source alters gene expression profile of intestinal epithelium in mice. Nutr. Cancer., 61: 146-55. doi:10.1080/01635580802372617

Wang W, Wu Z, Dai Z, Yang Y, Wang J, Wu G. 2013. Glycine metabolism in animals and humans: implications for nutrition and health. Amino Acids., 45: 463-77. doi:10.1007/s00726013-1493-1

Wang W, Dai Z, Wu Z, Lin G, Jia S, Hu S, Dahanayaka S, Wu G. 2014. Glycine is a nutritionally essential amino acid for maximal growth of milk-fed young pigs. Amino Acids., 46: 2037-45. doi:10.1007/s00726-014-1758-3

Wang X, Lan X, Radunz AE, Khatib H. 2015. Maternal nutrition during pregnancy is associated with differential expression of imprinted genes and DNA methyltranfereases in muscle of beef cattle offspring. J. Anim. Sci., 93: 35-40. doi:10.2527/jas.20148148

Wu G, Bazer FW, Dai Z, Li D, Wang J, Wu Z. 2014. Amino acid nutrition in animals: protein synthesis and beyond. Annu. Rev. Anim. Biosci., 2: 387-417. doi:10.1146/annurev-animal022513-114113

Yunita O, Yuwono M, Rantam FA. 2013. In vitro cytotoxicity assay of Sauropus androgynus on human mesenchymal stem cells. Toxicol. Environ. Chem., 95: 679-686. doi:10.1080/02772248.2013.798412

Zhai W, Gerard PD, Pulikanti R, Peebles ED. 2011. Effects of in ovo injection of carbohydrates on embryonic metabolism, hatchability, and subsequent somatic characteristics of broiler hatchlings. Poult. Sci., 90: 2134-43. doi:10.3382/ps.2011-01418

Zhang H-B, Wang ZS, Peng Q-H, Tan C, Zou H-W. 2014. Effects of different levels of protein supplementary diet on gene expressions related to intramuscular deposition in early-weaned yaks. Anim. Sci. J., 85: 411-9. doi:10.1111/asj.12161

Zhang H, Zhang X, Wang Z, Dong X, Tan C, Zou H, Peng Q, Xue B, Wang L, Dong G. 2015. Effects of dietary energy level on lipid metabolism-related gene expression in subcutaneous adipose tissue of Yellow breed x Simmental cattle. Anim. Sci. J., 86: 392-400. doi:10.1111/asj.12316

Zhao S, Wang J, Song X, Zhang X, Ge C, Gao S. 2010. Impact of dietary protein on lipid metabolism-related gene expression in porcine adipose tissue. Nutr. Metab (Lond)., 7: 6. doi: $10.1186 / 1743-7075-7-6$

Zhong W, Jiang Z, Zheng C, Lin Y, Yang L, Zou S. 2011. Relationship between proteome changes of Longissimus muscle and intramuscular fat content in finishing pigs fed conjugated linoleic acid. Br. J. Nutr., 105: 1-9. doi:10.1017/S0007114510003181

Zhou P, Zhang L, Li J, Luo Y, Zhang B, Xing S, Zhu Y, Sun H, Gao F, Zhou G. 2015. Effects of Dietary Crude Protein Levels and Cysteamine Supplementation on Protein Synthetic and Degradative Signaling in Skeletal Muscle of Finishing Pigs. PLoS One., 10: e0139393. doi:10.1371/journal.pone.0139393

Zhou Y, Fang L, Yu Y, Niu J, Jiang L, Cao H, Sun Q, Zen K, Dai C, Yang J. 2015. Erythropoietin protects tubular basement membrane by promoting bone marrow to release extracellular vesicles containing tPA-targeting miR-144. Am. J. Physiol. Ren. Physiol., 310: 27-40. doi:10.1152/ajprenal.00303.2015 